\title{
The weaver Mutation Causes a Loss of Inward Rectifier Current Regulation in Premigratory Granule Cells of the Mouse Cerebellum
}

\author{
Paola Rossi, Giovanna De Filippi, Simona Armano, Vanni Taglietti, and Egidio D'Angelo \\ Istituto di Fisiologia Generale, I-27100, Pavia, Italy, and Istituto Nazionale per la Fisica della Materia, Pavia Unit, Italy
}

Considerable interest has recently focused on the weaver mutation, which causes inward rectifier channel alterations leading to profound impairment of neuronal differentiation and to severe motor dysfunction in mice (Hess, 1996). The principal targets of mutation are cerebellar granule cells, most of which fail to differentiate and degenerate in a premigratory position (Rakic and Sidman, 1973a,b). Two hypotheses have been put forward to explain the pathogenetic role of mutant inward rectifier channels: namely that inward rectifier channel activity is either lacking (Surmeier et al., 1996) or altered (Kofuji et al., 1996; Silverman et al., 1996; Slesinger et al., 1996). We have examined this question by recording inward rectifier currents from cerebellar granule cells in situ at different developmental stages in wildtype and weaver mutant mice. In wild-type mice, the inward rectifier current changed from a G-protein-dependent activation to a constitutive activation as granule cells developed from premigratory to postmigratory stages. In weaver mutant mice, G-protein-dependent inward rectifier currents were absent in premigratory granule cells. A population of putative granule cells in the postmigratory position expressed a constitutive inward rectifier current with properties compatible with mutated GIRK2 channels expressed in heterologous systems. Because granule cells degenerate at the premigratory stage (Smeyne and Goldowitz, 1989), the loss of inward rectifier current and its regulation of membrane potential are likely to play a key role in the pathogenesis of weaver neuronal degeneration.

Key words: cerebellum; granule cell; channellopathy; weaver; inward rectifier; mouse
Ionic channels in neurons have the dual role of controlling membrane potential, thus allowing information coding that is essential for nervous system computation, and of regulating basal cellular processes such as growth, survival, and death (Spitzer, 1991). $\mathrm{K}^{+}$ channels play an important role in membrane potential regulation. In the weaver mutation, which causes neuronal degeneration and severe motor dysfunction in mice, an inward rectifier $\mathrm{K}^{+}$ channel is altered (Patil et al., 1995), and neuronal degeneration is observed in the cerebellum, substantia nigra, and hippocampus. In particular, most cerebellar granule cells fail to differentiate and die in ectopic position, causing severe disruption of the cerebellar network (Rakic and Sidman, 1973a,b; Sotelo and Changeux, 1974). Although the weaver mutation has been identified, its implications in terms of the pathogenetic mechanism remain largely unknown (Hess, 1996).

It has been shown that the weaver mutant channel expressed in oocytes has lower $\mathrm{K}^{+}$selectivity than the wild-type and has lost the modulatory G-protein control, thus becoming constitutively active (Slesinger et al., 1996). An anomalous $\mathrm{Na}^{+}$influx would cause membrane depolarization, possibly facilitating neuronal degeneration through secondary $\mathrm{Ca}^{2+}$-dependent processes (Kofuji et al., 1996). The absence of inward rectifier currents in granule cells in culture has suggested, however, that a loss of function was the main effect of the mutation (Surmeier et al., 1996). Here too, uncontrolled membrane depolarization would link the mutation to its pathological consequences. To be realistic, these hypotheses need to be based on a knowledge of the native

\footnotetext{
Received Dec. 8, 1997; revised Feb. 26, 1998; accepted Feb. 27, 1998.

Correspondence should be addressed to Dr. Egidio D'Angelo, Istituto di Fisiologia Generale, Via Forlanini 6, I-27100, Pavia, Italy.

This project was supported by Telethon Grant E.464 and by Istituto Nazionale per la Fisica della Materia.

Copyright (ㄷ) 1998 Society for Neuroscience $\quad 0270-6474 / 98 / 183537-11 \$ 05.00 / 0$
}

properties of the inward rectifier current and its effect on membrane potential. This is particularly relevant to granule cells, whose electroresponsiveness follows a specific developmental pattern in situ in terms of both inward rectification and action potential generation (D'Angelo et al., 1997). We therefore have compared inward rectifier currents in wild-type and weaver granule cells, as well as their G-protein modulation and effect on membrane potential, at different developmental stages using whole-cell patch-clamp recordings in acute cerebellar slices.

Here we show that in wild-type mice an inward rectifier current was elicited by G-protein activation in premigratory granule cells. The inward rectifier current changed voltage dependence and kinetics in postmigratory granule cells, thus becoming constitutively active. In weaver mutant mice, neither constitutive nor G-protein-dependent inward rectifier currents were observed in premigratory granule cells, providing compelling evidence that a loss of inward rectifier function occurs at the time of granule cell degeneration (Smeyne and Goldowitz, 1989; Surmeier et al., 1996). Some neurons in a deep position that expressed a constitutive inward rectifier current with properties compatible with those reported in reconstituted systems (Kofuji et al., 1996; Silverman et al., 1996; Slesinger et al., 1996) apparently corresponded to granule cells that had migrated and developed synaptic connections (Sotelo and Changeux, 1974). A loss of inward rectifier current at the premigratory stage and its regulation of membrane potential are therefore likely to play the key role in the pathogenesis of weaver neuronal degeneration.

\section{MATERIALS AND METHODS}

Patch-clamp whole-cell recordings were performed in granule cells in 250- $\mu$ m-thick mouse cerebellar slices (Edwards et al., 1989). Either wild-type (Swiss strain) or homozygous weaver mutant mice (B6CBACa$\left.\mathrm{A}^{\mathrm{w}-\mathrm{J}} / \mathrm{A}-w v\right)$ were used. Homozygous weaver mice were obtained from intercross mating of heterozygous weaver mice (Jackson) and amounted 
to $\sim 25 \%$ of littermates, consistent with simple mendelian segregation. Homozygous weaver mice were identified on the basis of their evident motor dysfunction, their dramatic cerebellar atrophy, and the abnormal morphology of cerebellar tissue during microscopic observation of the slices (Rakic and Sidman, 1973a,b). The slices were obtained on postnatal days 9-15 (day of birth = P1) from both wild-type and weaver mice. Cerebellar slices were prepared as reported previously (D'Angelo et al., 1995, 1997). Briefly, the mice were anesthetized with halothane (Aldrich, Milwaukee, WI) before they were decapitated. Krebs' solution for slice cutting and recovery contained (in $\mathrm{mm}$ ): $\mathrm{NaCl} 120, \mathrm{KCl} 2, \mathrm{MgSO}_{4} 1.2$, $\mathrm{NaHCO}_{3} 26, \mathrm{KH}_{2} \mathrm{PO}_{4} 1.2, \mathrm{CaCl}_{2} 2$, glucose 11 . This solution was equilibrated with $95 \% \mathrm{O}_{2}$ and $5 \% \mathrm{CO}_{2}, \mathrm{pH}$ 7.4. Slices were maintained at room temperature before being transferred to the recording chamber $(1.5 \mathrm{ml})$ mounted on the stage of an upright microscope (Zeiss Standard16). The preparations were superfused at a rate of $5-10 \mathrm{ml} / \mathrm{min}$ with Krebs' solution and maintained at $30^{\circ} \mathrm{C}$ with a feed-back Peltier device (HCC-100A; Dagan Corporation, Minneapolis, MN).

Data recording and analysis. The excitable responses and membrane currents of the granule cells were recorded using an Axopatch 200-A amplifier. The data were sampled with a TL-1 DMA Interface (sampling time $=250 \mu \mathrm{sec}$ for current-clamp recordings, $10 \mu \mathrm{sec}$ for voltage-clamp recordings) and analyzed with P-CLAMP software (Axon Instruments, Foster City, CA). Mossy fiber stimulation was performed with a bipolar tungsten electrode (Clark Instruments, Pangbourne, UK) via a stimulus isolation unit. The stimulating electrode was placed over the mossy fiber bundle, and stimuli were applied at a frequency of $0.1 \mathrm{~Hz}$. Control and test solutions were applied locally through a multi-barrel pipette. Perfusion of control solution was commenced before seal formation and was maintained until we switched to test solutions. QX-314 was obtained from Alomone (Tel-Aviv, Israel), and BAPTA tetrapotassium salt was obtained from Molecular Probes (Eugene, OR).

Patch pipettes were pulled from borosilicate glass capillaries (Hingelberg, Malsfeld, Germany) and had 8-12 M $\Omega$ resistance before a seal was formed with a filling solution containing (in $\mathrm{mM}$ ): potassium gluconate 126, $\mathrm{NaCl} 4, \mathrm{MgSO}_{4} 1, \mathrm{CaCl}_{2} 0.02$, BAPTA 0.1 , glucose 15 , ATP 3 , HEPES 5 ( $\mathrm{pH}$ was adjusted to 7.2 with $\mathrm{KOH}$ ), and either GTP 0.1 or GTP- $\gamma$-S 0.1 . This solution allowed current-clamp recordings of the excitable response as well as voltage-clamp recordings of the inward rectifier current. Considering that this solution was diluted by $10 \%$ before use, and assuming a 0.75 activity coefficient for $\mathrm{K}^{+}$salts (Pitzer and Mayorga, 1973), the nernstian reversal potential for $\mathrm{K}^{+}$ions was $-85.7 \mathrm{mV}$. Intracellular $\mathrm{Ca}^{2+}$ was buffered at $100 \mathrm{nM}$, similar to the resting $\mathrm{Ca}^{2+}$ concentration measured in granule cells (Marchetti et al., 1995).

After a gigaseal was formed (seal resistance was usually $>20 \mathrm{G} \Omega$ ), electrode capacitance was carefully cancelled before the patch was ruptured to allow for the electronic compensation of pipette charging during subsequent current-clamp recordings ( fast current-clamp mode). Depending on the high input-to-series resistance ratio, bridge balancing in current-clamp recordings proved of little effect and was not used routinely (D'Angelo et al., 1995). Membrane potential was measured relative to an agar-bridge reference electrode. Reported membrane potential values have been adjusted off-line for liquid-junction potentials (usually $<5 \mathrm{mV}$ ). Voltage-clamp recordings were used to record the inward rectifier current (see below) and to estimate the passive granule cell membrane properties. For this purpose, current transients were elicited by $10 \mathrm{mV}$ hyperpolarizing pulses from a holding potential of $-70 \mathrm{mV}$. The transients showed a monoexponential relaxation (time constant $=$ $81 \pm 27 \mu \mathrm{sec} ; n=40)$ and were used to estimate series resistance $(21.1 \pm$ $8.7 \mathrm{M} \Omega ; n=40)$ and input resistance and capacitance.

The experimental tracings were analyzed using P-Clamp (Axon Instruments) and Origin (Microcal Software, Northampton, MA) software. Data are reported as mean $\pm \mathrm{SD}$, and statistical comparisons were performed using Student's $t$ test.

Recording and analysis of inward rectifier current. The inward rectifier current was activated with hyperpolarizing voltage pulses from a holding membrane potential of $-40 \mathrm{mV}$. Alternatively, $I-V$ relationships were constructed using voltage ramps. Transient current and leakage subtraction were performed either by using tracings recorded before GTP- $\gamma-\mathrm{S}$ action or tracings in which the inward rectifier current was blocked pharmacologically, as explained in Results. The $I-V$ relationships were fitted with a modified Boltzmann equation (Hille and Schwarz, 1978) as follows:

$$
I(V)=\left[G_{\max }\left(V-V_{\text {rev }}\right)\right] /\left[1+\exp \left(\left(V-V_{1 / 2}\right) / k\right)\right]
$$

where $G_{\max }$ is the maximal conductance, $V_{\text {rev }}$ is the reversal potential, $V_{1 / 2}$ is the potential at which the current is half-activated, and $k$ is the voltage dependence of activation $\left(V^{-1}\right)$. Once $V_{\text {rev }}$ and $G_{\max }$ were known, and because $G(V)=I(V) /\left(V-V_{\text {rev }}\right)$, activation curves of the form:

$$
G / G_{\max }=1 /\left[1+\exp \left(\left(V-V_{1 / 2}\right) / k\right)\right]
$$

were plotted and used to compare inward rectifier voltage dependencies.

\section{RESULTS}

We investigated inward rectifier currents and their relationship with granule cell electroresponsiveness in wild-type and weaver mutant granule cells in acute mice cerebellar slices. Recordings were performed at different depths in the cerebellar cortex, allowing the electrophysiological properties to be correlated with neuronal developmental stage. Unless stated otherwise, the granule cells were recorded at P10-P15.

\section{Electroresponsiveness in wild-type granule cells}

In wild-type mice, at P10-P15 the germinal layer and the premigratory zone, constituting the external granular layer (EGL) of the cerebellar cortex, are clearly recognizable (Fig. 1A) (Rakic and Sidman, 1973a). After migration, the granule cells populate the internal granular layer (IGL), become synaptically connected with mossy fibers, and complete their maturation. The electrophysiological properties of granule cells recorded at different depths are shown in Figure $1 B$ and Table 1.

In an initial set of experiments we used patch pipettes containing $100 \mu \mathrm{M}$ GTP (Fig. 1B). The granule cells in the germinal layer $(a)$ and premigratory zone $(b)$ of the EGL showed a rather high resting membrane potential $(a,-24 \pm 1.4 \mathrm{mV}, n=8 ; b,-22.9 \pm$ $3, n=11$ ). These cells did not generate any action potential when they were injected with depolarizing currents, although the membrane had previously been hyperpolarized with a constant negative current. The injection of hyperpolarizing pulses did not reveal any inward rectification. The granule cells in the IGL showed either immature $(c 1)$ or mature $(c 2)$ electrical responses, which were distinguished on the basis of the nature of action potentials and the presence of inward rectification (D'Angelo et al., 1997). Immature responses consisted of slow spikes, absence of inward rectification, and high resting potential $(c 1,-36.3 \pm 9.1$ $\mathrm{mV} ; n=8)$. Mature responses consisted of fast spikes, inward rectification, and a negative resting membrane potential ( $c 2$ $-57.5 \pm 10.6 \mathrm{mV} ; n=6)$. Similar granule cells were most commonly observed after P21 (seven of eight; data not shown), when migration is concluded and the EGL is no longer evident. The $V-I$ relationships shown in Figure $1 C$ compare voltage response elicited by current injection into the granule cells, evidencing constitutive inward rectification in the granule cell that generates fast spikes.

When the nonhydrolyzable G-protein activator GTP- $\gamma$-S was included in the patch pipette, inward rectification could be induced in postmitotic granule cells that did not show it constitutively (Fig. 1D). In these cells GTP- $\gamma-\mathrm{S}$ induction of inward rectification was associated with a significant lowering in resting membrane potential $(b,-13 \pm 3.7 \mathrm{mV}, n=9 ; c 1,-16.1 \pm 4.3$ $\mathrm{mV}, n=8 ; p<0.02$ in both cases). Inward rectification was manifest as a decrease in input resistance in $V-I$ plots. Inward rectification extended well over the $\mathrm{K}^{+}$reversal potential $(-85.6$ $\mathrm{mV}$ ) into the resting membrane potential region, as would be expected from current voltage dependence measured in voltageclamp experiments (see below). No significant inward rectification or membrane potential changes were observed in granule 

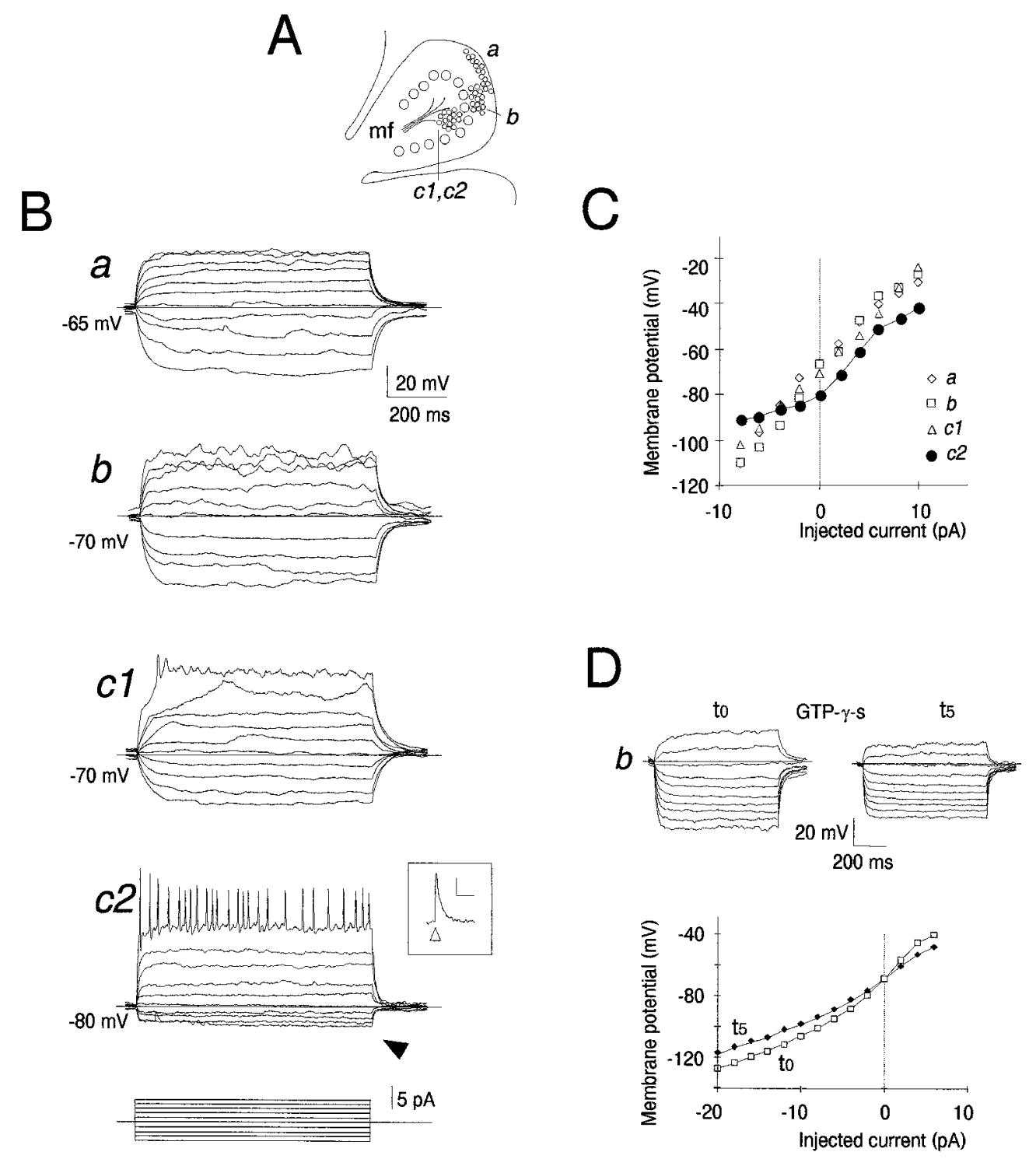

Figure 1. Electroresponsiveness in developing wild-type granule cells. $A$, Schematic view of a cerebellar slice at P15 (after Rakic and Sidman, 1973 a,b; Sotelo and Changeux, 1974). The indices $a$ through $c$ correspond to different positions in the cortex from which granule cells were recorded $[a=$ germinal layer, $b=$ premigratory zone, $c 1=$ postmigratory zone (immature cells), $c 2=$ postmigratory zone (mature cells) $]. B$, Positive and negative current pulses have been injected into granule cells recorded using patch pipettes containing GTP and maintained at the indicated resting potential with constant current injection. No inward rectification can be observed in granule cells $a$-c1, whereas a marked nonsagging inward rectification (arrowhead) is expressed in the granule cell $c 2$ (also see D'Angelo et al., 1995, 1997). This granule cell is synaptically connected, as demonstrated by the EPSP generated by mossy fiber stimulation (inset: $\Delta$ mossy fiber stimulation. Calibration: $10 \mathrm{mV}, 100 \mathrm{msec}$ ). The current-clamp protocol is illustrated at the bottom. $C$, Voltage-current plot for the cells in $B$. Membrane potential has been averaged over the last $500 \mathrm{msec}$ of the tracings. $D$, Voltage recordings from a granule cell of the premigratory zone using a patch pipette containing GTP- $\gamma$-S. Although the cell shows no inward rectification at the beginning of recording $\left(t_{0}\right)$, inward rectification developed after $5 \mathrm{~min}\left(t_{5}\right)$. To compare the effect of injected current pulses, tracings have been recorded from an arbitrary membrane potential $(-70 \mathrm{mV})$ maintained with constant current injection. Therefore the $14 \mathrm{mV}$ hyperpolarization occurring with GTP- $\gamma$-S action is not seen in the figure. The bottom voltage-current plot reports membrane potentials averaged over the last $500 \mathrm{msec}$ of the tracings, illustrating the induction of inward rectification by GTP- $\gamma$-S.

cells of the germinal layer $[a, 4 \pm 3.2 \mathrm{mV}, n=8$; not significant (NS)], or in fast spiking granule cells of $\operatorname{IGL}(c 2,1.1 \pm 3.2 \mathrm{mV}$, $n=7$; NS). It should be noted that both the constitutive and GTP- $\gamma$-S dependent inward rectification did not sag, indicating that the underlying current had activation kinetics that were faster than passive membrane charging.

\section{G-protein modulation of the inward rectifier current in wild-type granule cells}

The nature of the current generating inward rectification, and its modulation by G-proteins (Wickman and Clapham, 1995), has been investigated (Fig. 2A), and the time course of GTP- $\gamma-\mathrm{S}$ action has been compared with that of GTP (Fig. $2 B$ ).

(a) In the germinal layer, no inward rectifier current could be demonstrated, despite the presence of GTP- $\gamma-\mathrm{S}$ in the patch pipette (8 of 8$)$.

(b) In the premigratory zone, the granule cells showed inward rectifier current expression during GTP- $\gamma-S$ internal perfusion $\left(G-I_{\mathrm{IR}} ; 9\right.$ of 10$)$. No inward rectifier current was observed at the beginning of the recording or when patch pipettes containing GTP were used (9 of 9), indicating the absence of constitutive 
Table 1. Electrophysiological properties of wild-type and weaver granule cells

\begin{tabular}{|c|c|c|c|c|}
\hline & & $C_{\mathrm{m}}(\mathrm{pF})$ & $g_{\text {leak }}(\mathrm{nS})$ & $\begin{array}{c}g_{\text {leak }} / C_{\mathrm{m}} \\
(\mathrm{nS} / \mathrm{pF})\end{array}$ \\
\hline \multirow[t]{4}{*}{ Wild-type } & $a(n=8)$ & $3.5 \pm 1.6$ & $0.54 \pm 0.18$ & 0.15 \\
\hline & $b(n=6)$ & $4.5 \pm 0.9$ & $0.3 \pm 0.1$ & 0.07 \\
\hline & $c 1(n=7)$ & $3.1 \pm 1.1$ & $0.3 \pm 0.1$ & 0.1 \\
\hline & $c 2(n=7)$ & $2.9 \pm 0.9$ & $0.6 \pm 0.2$ & 0.21 \\
\hline \multirow[t]{3}{*}{ Weaver } & $a_{\mathrm{wv}}(n=8)$ & $2.9 \pm 0.5$ & $0.5 \pm 0.3$ & 0.17 \\
\hline & $b_{\mathrm{wv}}(n=9)$ & $4.6 \pm 0.3$ & $0.6 \pm 0.4$ & 0.13 \\
\hline & $c_{\mathrm{wv}}(n=6)$ & $7.9 \pm 2.5^{*}$ & $1.2 \pm 1.1^{*}$ & 0.15 \\
\hline
\end{tabular}

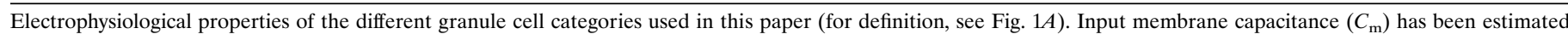

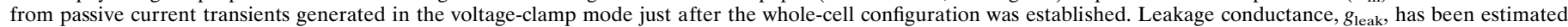

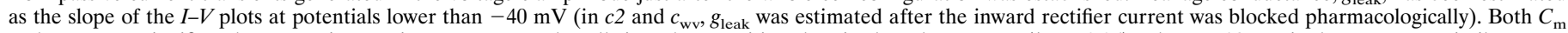
and $g_{\text {leak }}$ were significantly greater in putative weaver granule cells in a deep position than in the other groups $\left({ }^{*} p<0.05\right)$. The $g_{\text {leak }} / C_{\mathrm{m}}$ ratio, however, was similar.

A
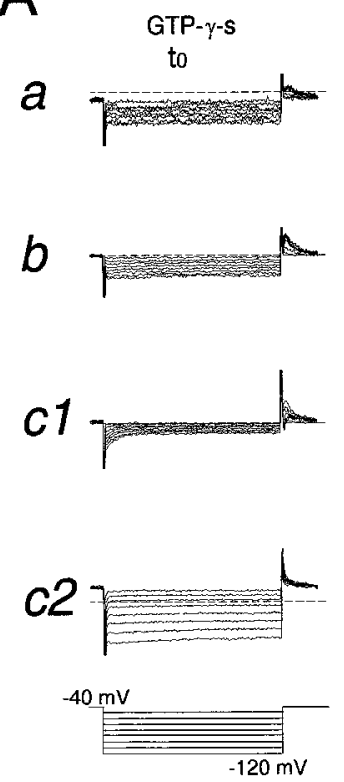
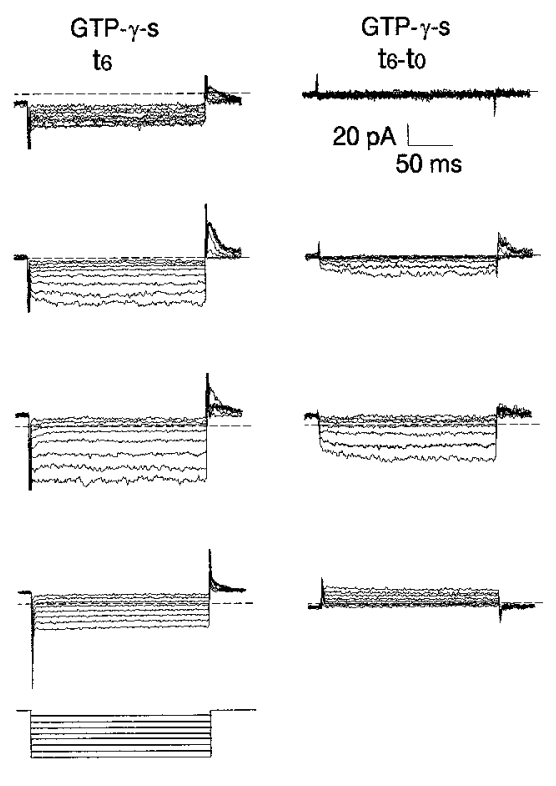
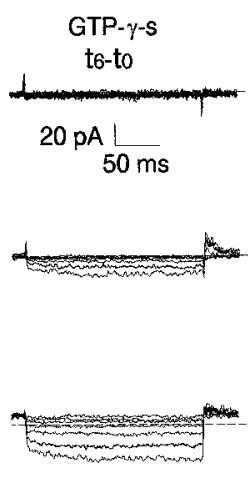

$50 \mathrm{~ms}$

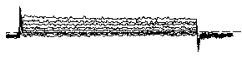

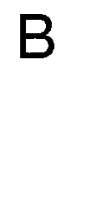
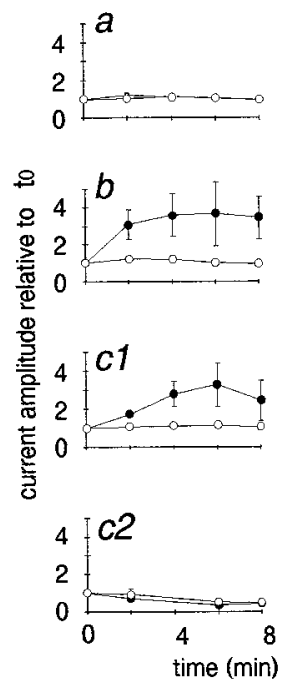

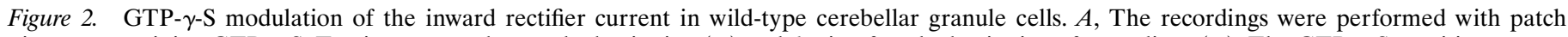

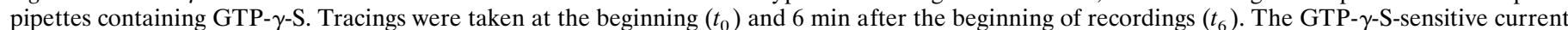

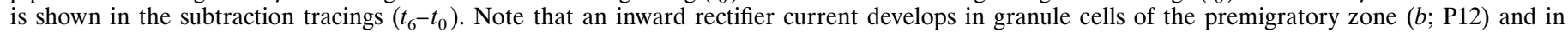

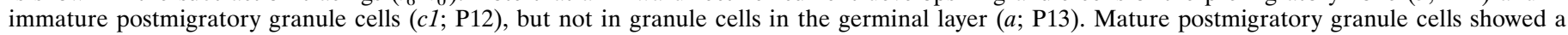

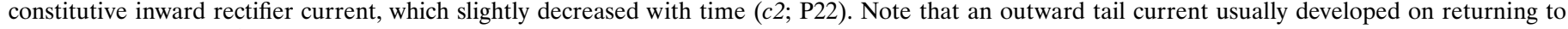

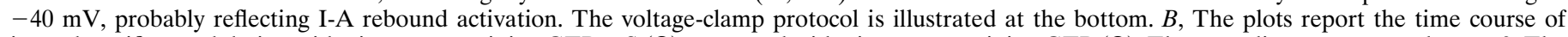

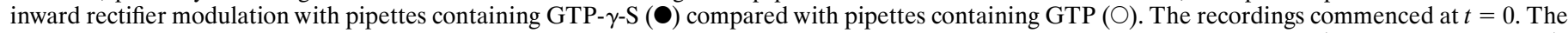

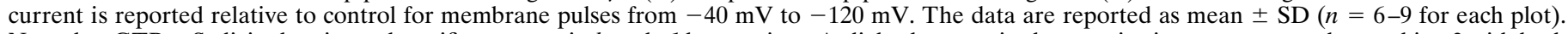

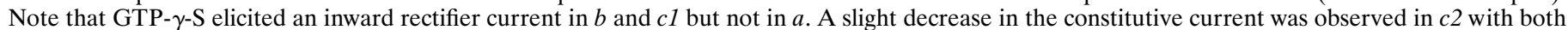
GTP- $\gamma$-S and GTP. Labels $a-c$ have the same meaning as in Figure $1 \mathrm{~A}$.

activation. The time course of GTP- $\gamma$-S action was similar to that reported previously in culture (Surmeier et al., 1996).

(c1) In the IGL, some of the granule cells (7 of 12) showed inward rectifier current modulation during GTP- $\gamma$-S internal perfusion $\left(G-I_{\mathrm{IR}}\right)$, but no inward rectifier current was measured at the beginning of the recording. Inward rectifier current modulation in these granule cells was therefore similar to that in cells in the premigratory zone. Accordingly, when we used patch pipettes containing GTP, no inward rectifier current was observed in the majority of granule cells (7 of 10), whereas a constitutive inward rectifier current was observed in the remaining granule cells ( 3 of 10; see point $c 2$ ).

(c2) In the IGL, some of the granule cells showed a constitutive inward rectifier current $\left(C-I_{\mathrm{IR}}\right)$. In addition to being observed at the beginning of the recordings with pipettes containing GTP- $\gamma$-S (5 of 12), $C-I_{\text {IR }}$ was also observed when patch pipettes containing GTP were used (3 of 10). At a more advanced developmental stage (P21-P22), $C-I_{\text {IR }}$ was recorded in the majority of granule cells (seven of nine; data not shown).

These results indicate that the inward rectifier current follows a precise developmental time course in situ, leading from G-protein-dependent to constitutive activation.

\section{Biophysical and pharmacological properties of the inward rectifier current in wild-type mice}

$G-I_{\text {IR }}$ and $C-I_{\text {IR }}$ displayed similar pharmacological sensitivity (Fig. $3 A$ ). These currents were completely blocked by $1 \mathrm{~mm} \mathrm{Ba}^{2+}$ $\left(97.2 \pm 6.1 \% G-I_{\mathrm{IR}}\right.$ block, $n=5 ; 98.6 \pm 4.3 \% C-I_{\mathrm{IR}}$ block, $n=$ 
A1
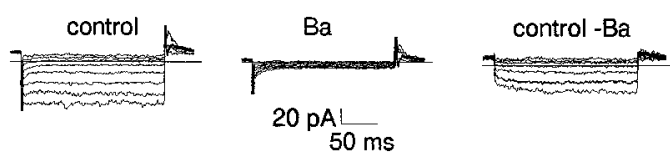

A2

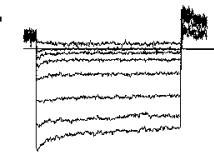

$-40 \mathrm{mV}$
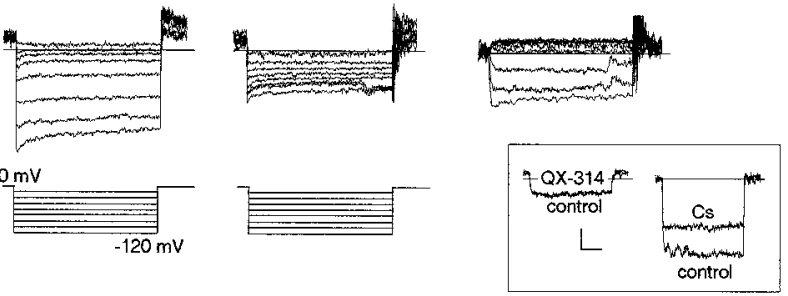
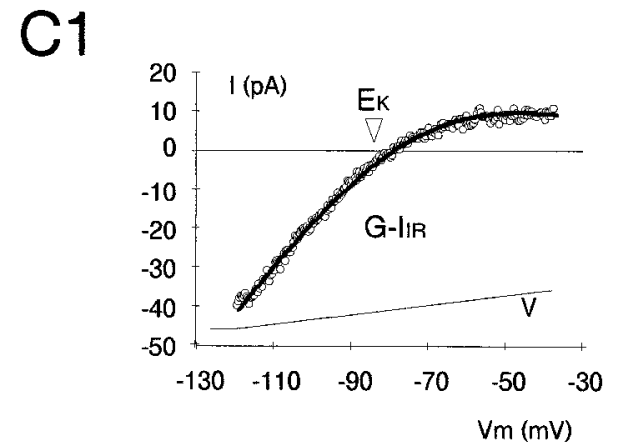

B2
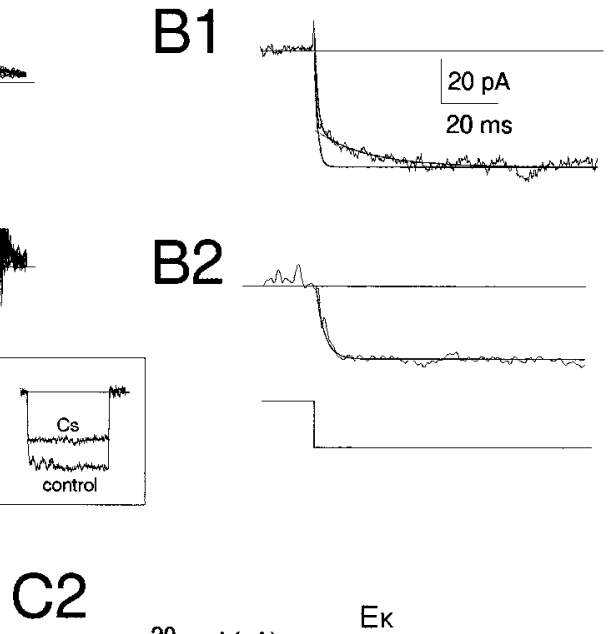

Figure 3. Biophysical and pharmacological properties of the wild-type inward rectifier current. $A 1, A 2$, Both the current generated by GTP- $\gamma$-S ( $A 1$, $\left.G-I_{\mathrm{IR}}\right)$ and that constitutively expressed $\left(A 2, C-I_{\mathrm{IR}}\right)$ in granule cells were blocked by $1 \mathrm{mM} \mathrm{Ba}^{2+}$. The $\mathrm{Ba}^{2+}$-sensitive currents have been obtained by subtraction (control - Ba). The voltage-clamp protocol is illustrated at the bottom. The inset illustrates the insensitivity of $G-I_{\mathrm{IR}}$ to $100 \mu \mathrm{M} \mathrm{QX}-314$ and partial block by $1 \mathrm{~mm} \mathrm{Cs}^{+}$in two different cells (the tracings are leakage-subtracted, demonstrating the extent of block). B1, B2, Tracings obtained using the subtraction protocol shown in $A$ have been used for kinetic analysis. $G-I_{\mathrm{IR}}(B 1)$ was fitted with a double exponential function of the form $i(t)=A 1 \times$ $\exp \left(-t / \tau_{1}\right)+A 2 \times \exp \left(-t / \tau_{2}\right)+C$. The individual exponential components as well as the biexponential function are superimposed on the experimental tracing $\left(A 1=40.2 \mathrm{pA} ; \tau_{1}=1.1 \mathrm{msec} ; A 2=16.1 \mathrm{pA} ; \tau_{2}=18.5 \mathrm{msec} ; C=-42\right)$. $C-I_{\mathrm{IR}}(B 2)$ was fitted with a single exponential function of the form $i(t)=A 1 \times \exp \left(-t / \tau_{1}\right)+C$. The monoexponential function is superimposed on the experimental tracing $\left(A 1=31.6 \mathrm{pA} ; \tau_{1}=2.7 \mathrm{msec} ; C=-31.6\right.$ $\mathrm{pA})$. The tracings in $B 1$ and $B 2$ were generated by a voltage pulse from $-40 \mathrm{mV}$ to $-120 \mathrm{mV}$. $C 1$, $C 2$, The voltage dependence of the fast inward rectifier current components of $G-I_{\mathrm{IR}}(C 1)$ or $C-I_{\mathrm{IR}}(C 2)$ was obtained using a voltage-ramp protocol. The experimental points have been fitted to Equation 1 to yield the following parameters: $(C 1) G_{\max }=1.17 \mathrm{nS} ; V_{\text {rev }}=-79.66 \mathrm{mV} ; V_{1 / 2}=-73.33 \mathrm{mV} ; k=24.4 \mathrm{mV}^{-1} ;(C 2) G_{\max }=2.78 \mathrm{nS} ; V_{\text {rev }}=-84.8 \mathrm{mV}$; $V_{1 / 2}=-82.4 \mathrm{mV} ; k=8.94 \mathrm{mV}^{-1}$. The voltage-ramp protocol is indicated at the bottom.

4) but were only partially blocked by $5 \mathrm{~mm} \mathrm{Cs}^{+}(68.4 \pm 25.4 \%$ $G-I_{\text {IR }}$ block, $n=8 ; 58.6 \pm 41.6 \% C-I_{\text {IR }}$ block, $\left.n=4\right)$. Moreover, these currents were insensitive to $100 \mu \mathrm{M}$ QX-314 $(3.5 \pm 2.2 \%$ $G-I_{\mathrm{IR}}$ block, $n=4 ; 16.6 \pm 19.3 \% C-I_{\mathrm{IR}}$ block, $\left.n=4\right)$, a cationic channel blocker known to affect $\mathrm{Na}^{+}$channels as well as inward rectifier channels with partial $\mathrm{Na}^{+}$permeability (Perkins and Wong, 1995; Kof uji et al., 1996; Slesinger et al., 1996). $G-I_{\mathrm{IR}}$ and $C-I_{\text {IR }}$ were analyzed using tracings taken after pharmacological block with $1 \mathrm{~mm} \mathrm{Ba}^{2+}$ for leakage and transient current subtraction (Fig. 3A).

$G-I_{\text {IR }}$ did not show inactivation (Fig. 3A1). $G-I_{\text {IR }}$ activation comprised a fast and a slow component and could be fitted with a biexponential function (Fig. 3B1). The fast component had almost voltage-independent time constants in the submillisecond range and accounted for $84 \%$ of $G-I_{\mathrm{IR}}$ amplitude at $-120 \mathrm{mV}$. The slow component had time constants in the $100 \mathrm{msec}$ range and was better resolved at potentials lower than $-100 \mathrm{mV}$. The fast component therefore accounted for most of the $G-I_{\text {IR }}$ in the physiological range of membrane potentials and should correspond to the "instantaneous" rectification reported in other papers (Kof uji et al., 1996; Surmeier et al., 1996). The slow component may itself be composite (Doupnik et al., 1995), although no different subcomponents were detectable in the time scale used here. The voltage dependence of the fast $G-I_{\mathrm{IR}}$ component was investigated using a voltage-ramp protocol (Fig. $3 \mathrm{Cl}$ ). The $I-V$ relationship was fitted with Equation 1, yielding the Boltzmann parameters $V_{1 / 2}$ and $k$ as well as maximum conductance $\left(G_{\max }\right)$ and reversal potential $\left(V_{\text {rev }}\right)$ (Table 2). Because of its (1) reversal potential close to that of $\mathrm{K}^{+}$ions, (2) fast kinetics, (3) high sensitivity to $\mathrm{Ba}^{2+}$ block, and (4) modulation by G-proteins, $G-I_{\mathrm{IR}}$ appeared as the native counterpart of GIRK2-containing channels measured in reconstituted systems (Duprat et al., 1995; Kof uji et al., 1995; Krapivinsky et al., 1995; Silverman et al., 1996; Slesinger et al., 1996). A similar current has been reported in mice granule cells in culture (Surmeier et al., 1996).

$C-I_{\mathrm{IR}}$ is shown in Figure $3 A 2 . C-I_{\mathrm{IR}}$ activated monoexponentially with time constants in the millisecond range, whereas no slow components could be detected (Fig. 3B2). The voltage dependence of $C-I_{\mathrm{IR}}$ was investigated using a voltage-ramp protocol (Fig. 3C2). The results of an analysis similar to that used for $G-I_{\text {IR }}$ are reported in Table 2. No such constitutive fast inward rectifier current has been reported previously in granule cells in culture, although its existence was suggested by voltage recordings in slice preparations (D’Angelo et al., 1995, 1997).

Table 2 and Figure 4 condensed data on the biophysical properties of $G-I_{\mathrm{IR}}$ and $C-I_{\mathrm{IR}} \cdot C-I_{\mathrm{IR}}$ had steeper voltage dependence 


\begin{tabular}{llllc}
\hline \multicolumn{5}{l}{ Table 2. Gating properties of inward rectifier currents in wild-type and weaver granule cells } \\
& $G_{\max }(\mathrm{nS})$ & $V_{\mathrm{rev}}(\mathrm{mV})$ & $V_{1 / 2}(\mathrm{mV})$ & $k\left(\mathrm{mV}^{-1}\right)$ \\
\hline$G-I_{\mathrm{IR}}(n=8)$ & $2.6 \pm 1.6$ & $-80.5 \pm 6.6^{*}$ & $-81.9 \pm 8.3$ & $25.1 \pm 5.7^{* *}$ \\
$C-I_{\mathrm{IR}}(n=7)$ & $1.4 \pm 1.2$ & $-84.2 \pm 7.7^{* *}$ & $-86.3 \pm 7.2$ & $8.1 \pm 0.7^{*}$ \\
$w v-I_{\mathrm{IR}}(n=6)$ & $4.3 \pm 2.6$ & $-64.1 \pm 6.3$ & $-71.6 \pm 1.9$ & $11.6 \pm 1.4$
\end{tabular}

Average parameter values characterizing inward rectifier current activation were obtained using Equation 1 . The reversal potential $\left(V_{\mathrm{rev}}\right)$ was significantly less negative in $w v-I_{\mathrm{IR}}$ than in either $C-I_{\mathrm{IR}}\left({ }^{* *} p<0.01\right)$ or $G-I_{\mathrm{IR}}\left({ }^{* *} p<0.002\right)$. The voltage-dependence of activation $(k)$ was significantly different in $w v-I_{\mathrm{IR}}$ as compared with $C-I_{\mathrm{IR}}\left({ }^{*} p<0.01\right)$ and $G-I_{\mathrm{IR}}$ $\left({ }^{* *} p<0.001\right)$. Once the maximum conductance $\left(G_{\max }\right)$ was normalized for the membrane capacitance, the sequence $G-I_{\mathrm{IR}}$ $(0.68 \pm 0.4 \mathrm{nS} / \mathrm{pF})>w v-I_{\mathrm{IR}}(0.56 \pm 0.3 \mathrm{nS} / \mathrm{pF})>C-I_{\mathrm{IR}}(0.41 \pm 0.33 \mathrm{nS} / \mathrm{pF})$ was obtained, with $w v-I_{\mathrm{IR}}$ proving to be statistically indistinguishable from $C-I_{\mathrm{IR}}$ or $G-I_{\mathrm{IR}}$.

Figure 4. Average kinetics of wild-type inward rectifier currents. $A$, Average $I-V$ plots of the fast inward rectifier current components of $G-I_{\mathrm{IR}}$ and $C-I_{\mathrm{IR}}$ have been reconstructed using Equation 1 and the average values reported in Table 2. $B$, Normalized activation curves of $G-I_{\text {IR }}$ and $C-I_{\text {IR }}$ have been reconstructed using Equation 2. $C$, Voltage dependence of the fast activation time constant of $G-I_{\mathrm{IR}}$ and of the activation time constant of $C-I_{\mathrm{IR}} \cdot A-C$ show that activation kinetics are faster but less voltage dependent in $C-I_{\mathrm{IR}}$ than in $G-I_{\mathrm{IR}}$.

than $G-I_{\text {IR }}$, and an activation time constant that was slower than the fast component of $G-I_{\mathrm{IR}}$. Together with constitutive activation and the absence of a slow component, these were the major properties of $C-I_{\mathrm{IR}}$ that distinguished it from $G-I_{\mathrm{IR}}$.

\section{Electroresponsiveness in weaver granule cells}

In weaver mutant mice, cerebellar architecture is profoundly disrupted (Fig. 5A) (Rakic and Sidman, 1973a; Sotelo and Changeux, 1974). Below the germinal layer, large neurons probably corresponding to ectopic Purkinje cells were surrounded by groups of granule cells, and no IGL could be identified. The small neurons beside or below Purkinje cells in a deep position should correspond to granule cells "which have achieved a complete migration reaching their normal position and developing their normal connections" (Sotelo and Changeux, 1974), although no direct differentiation vis-à-vis other neuronal types (stellate or basket cells) could be achieved in the present experiments.

The granule cells displayed different electrophysiological behavior depending on their location, as shown in Figure $5 B$ and reported in Table 1 for slices obtained at P10-P15. When patch pipettes containing GTP were used, the granule cells in the germinal layer $\left(a_{\mathrm{wv}}\right)$ and in the premigratory zone $\left(b_{\mathrm{wv}}\right.$, recorded at $50-100 \mu \mathrm{m}$ from the pial surface) appeared similar to those of
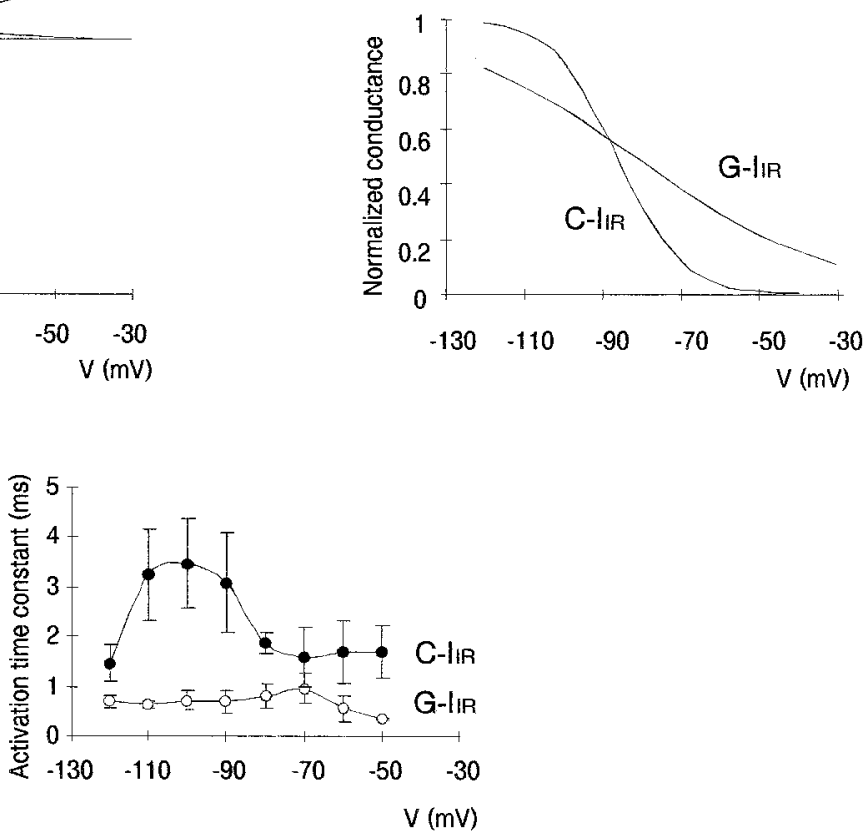

the wild type. They had a rather high resting membrane potential $\left(a_{\mathrm{wv}},-22 \pm 7.2 \mathrm{mV}, n=8 ; b_{\mathrm{wv}},-32 \pm 2.7, n=10\right)$ and did not generate either action potentials or inward rectification during current injection. Some of the granular neurons in a deeper position $\left(c_{\mathrm{wv}}\right.$, recorded at $100-200 \mu \mathrm{m}$ from the pial surface), however, had a more negative resting membrane potential $(-57.6 \pm 5.4 \mathrm{mV}, n=6)$, generated action potentials (in three neurons a solitary fast spike was measured, whereas the other three neurons generated a fast repetitive spike discharge), and showed sagging inward rectification. These neurons therefore exhibited a resting membrane potential and spike discharge comparable to those of wild-type granule cells at an advanced developmental stage in the IGL, although the nature of the inward rectification was different (compare Fig. $1 A$, panel $C 2$ ). These neurons could be activated by afferent fiber stimulation with a time delay of $1.5 \mathrm{msec}$ for EPSP activation (Fig. $5 B$, inset). These neurons therefore are putative postmigratory granule cells that developed until they formed functional synapses. The $V-I$ relationships in Figure $5 B$ show that subthreshold voltage responses lacked inward rectification in premigratory weaver granule cells, whereas a constitutive inward rectification was evident in putative postmigratory granule cells. 

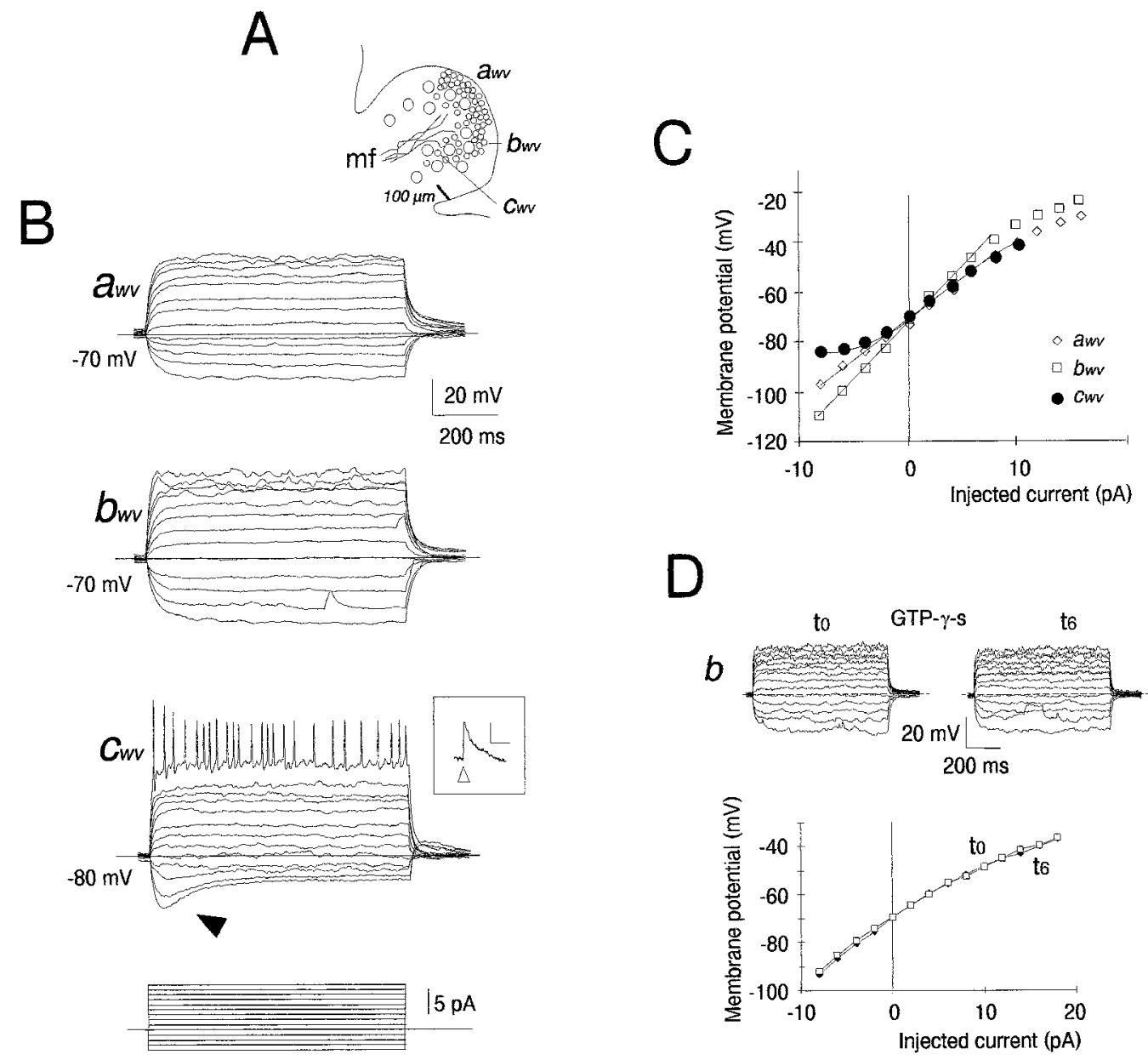

D
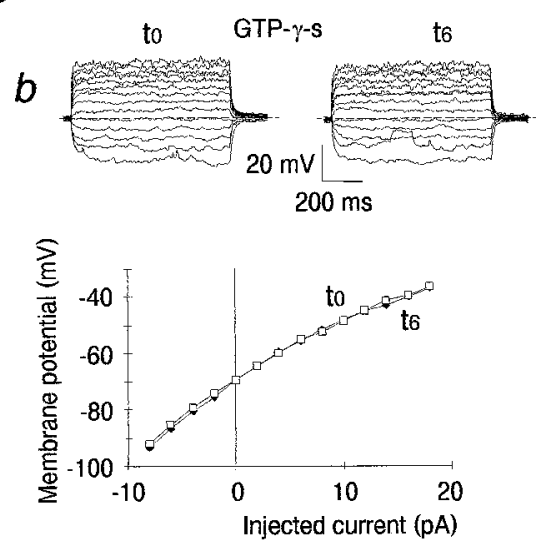

Figure 5. Electroresponsiveness in developing weaver granule cells. $A$, Schematic view of the homozygous weaver cerebellum (after Rakic and Sidman, 1973a,b; Sotelo and Changeux, 1974). The indices $a_{\mathrm{wv}}-c_{\mathrm{wv}}$ correspond to different positions in the cortex, as illustrated in the top inset ( $a_{\mathrm{wv}}=$ germinal layer, $b_{\mathrm{wv}}=$ premigratory zone, $c_{\mathrm{wv}}=$ deep layer). $B$, Positive and negative current pulses have been injected in granule cells recorded in P10-P15 acute slices of the cerebellar vermis using patch pipettes containing GTP, and maintained at the indicated resting potential with constant current injection. Note that no inward rectification can be observed in the granule cells $a_{\mathrm{wv}}-b_{\mathrm{wv}}$, whereas marked sagging inward rectification (arrowhead) is expressed in the granule cell $c_{\mathrm{wv}}$ (also see D'Angelo et al., 1995, 1997). This granule cell is synaptically connected, as demonstrated by the EPSP generated by mossy fiber stimulation (inset: $\Delta$ mossy fiber stimulation. Calibration: $10 \mathrm{mV}, 100 \mathrm{msec}$ ). The current-clamp protocol is illustrated at the bottom. $C$, Voltage-current plot for the cells in $B$. Membrane potential has been averaged over the last $500 \mathrm{msec}$ of the tracings. $D$, Voltage recordings from a granule cell of the premigratory zone using a patch pipette containing GTP- $\gamma$-S. Unlike wild-type granule cells, no inward rectification developed after 5 min of GTP- $\gamma-\mathrm{S}$ internal perfusion ( $t_{6}$ as compared with $t_{0}$ ), nor was membrane hyperpolarization measured (the tracings have been recorded from an arbitrary membrane potential of $-70 \mathrm{mV}$ ). The voltage-current plot at the bottom reports membrane potentials averaged over the last $500 \mathrm{msec}$ of the tracings, illustrating the absence of inward rectification induction.

A major difference between weaver and wild-type granule cells was revealed using patch pipettes containing GTP- $\gamma$-S. Despite the apparent similarity of their electrical response to the wildtype cells, the weaver granule cells showed neither induction of inward rectification (Fig. $5 D$ ) nor hyperpolarization from rest during GTP- $\gamma$-S perfusion $\left(a_{\mathrm{wv}}-5.1 \pm 4.9 \mathrm{mV}, n=8 ; b_{\mathrm{wv}} 0 \pm 3.3\right.$ $\mathrm{mV}, n=10 ; c_{\mathrm{wv}} 5.6 \pm 3.2 \mathrm{mV}, n=6$; NS in all cases).

\section{G-protein modulation of the inward rectifier current in weaver granule cells}

As in wild-type granule cells, the nature of the inward rectifier current in weaver mutant mice, and its G-protein sensitivity, were investigated (Fig. 6A), and the time course of GTP- $\gamma$-S action was compared with that of GTP (Fig. 6B).

$\left(a_{\mathrm{wv}}\right)$ As in wild-type mice, granule cells in the germinal layer did not show any inward rectifier currents despite the presence of GTP- $\gamma$-S in the patch pipette (10 of 10).

$\left(b_{\mathrm{wv}}\right)$ Unlike in wild-type mice, granule cells in the premigra- tory zone did not show any inward rectifier currents, despite the presence of GTP- $\gamma-\mathrm{S}$ in the patch pipette (14 of 14). These granule cells were interesting, because they may be cells in which mutation has caused a loss of G-protein sensitivity in the inward rectifier current (Surmeier et al., 1996). The weaver currents therefore differed from wild-type inward rectifier currents in their G-protein-dependent modulation.

$\left(c_{\mathrm{wv}}\right)$ Putative postmigratory granule cells showed a constitutive inward rectifier current with anomalous properties, $w v-I_{\text {IR }}(6$ of 7) (Fig. 6C). In addition to being observed at the beginning of the recordings in the presence of GTP- $\gamma-\mathrm{S}, w v-I_{\mathrm{IR}}$ was observed also when patch pipettes containing GTP were used (7 of 7).

\section{Biophysical and pharmacological properties of the inward rectifier current in putative weaver granule cells}

The weaver inward rectifier current, $w v-I_{\text {IR }}$, showed distinctive pharmacological properties. Unlike the wild-type inward rectifi- 


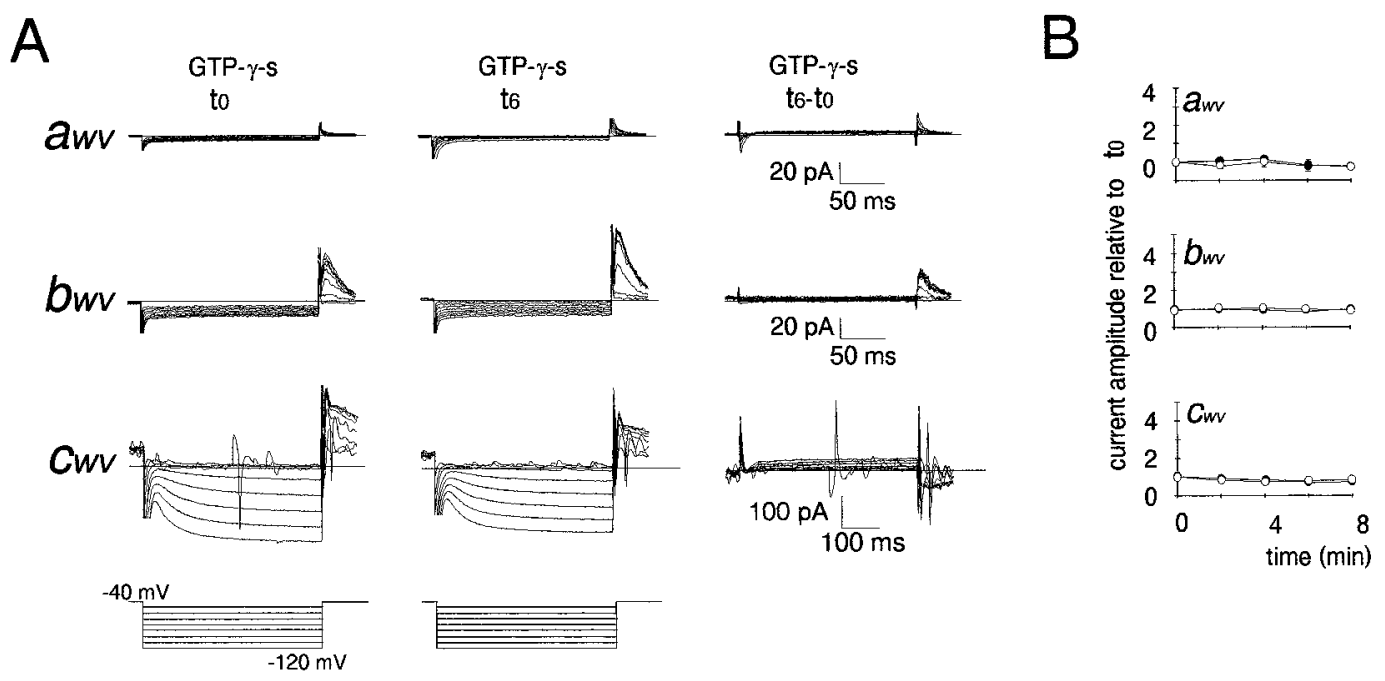

Figure 6. GTP- $\gamma$-S modulation of the inward rectifier current in weaver cerebellar granule cells. $A$, The recordings were performed with patch pipettes containing GTP- $\gamma$-S. Tracings were taken at the beginning $\left(t_{0}\right)$ and 6 min after the beginning of recordings $\left(t_{6}\right)$. The GTP- $\gamma$-S-sensitive current is shown in the subtraction tracings $\left(t_{6}-t_{0}\right)$. Note that no inward rectifier current develops in either granule cells in the premigratory zone $\left(b_{\mathrm{wv}}\right)$ or those in the germinal layer $\left(a_{\mathrm{wv}}\right)$. Granule cells in a deep position showed a constitutive inward rectifier current, which slightly decreased with time $\left(c_{\mathrm{wv}}\right.$; note the different scale than in $\left.a_{\mathrm{wv}}, b_{\mathrm{wv}}\right)$. The voltage-clamp protocol is illustrated at the bottom. $B$, The plots report the time course of inward rectifier modulation with GTP- $\gamma$-S-containing pipettes $(\bullet)$ compared with GTP-containing pipettes $(\bigcirc)$. The recordings commenced at $t=0$. The current is reported relative to control for membrane pulses from $-40 \mathrm{mV}$ to $-120 \mathrm{mV}$. The data are reported as mean $\pm \mathrm{SD}(n=5-10$ for each plot). Note that neither GTP- $\gamma-\mathrm{S}$ nor GTP elicited any inward rectifier current in $a_{\mathrm{wv}}$ or $b_{\mathrm{wv}}$. A slight decrease in the constitutive current was observed in $c_{\mathrm{wv}}$ with either GTP- $\gamma-\mathrm{S}$ or GTP. Labels $a_{\mathrm{wv}}-c_{\mathrm{wv}}$ have the same meanings as in Figure $5 A$.

ers, $w v-I_{\mathrm{IR}}$ was inhibited by $100 \mu \mathrm{M}$ QX-314 (60.6 $\pm 19.3 \%$ block; $n=5$ ) (Fig. 7A). Sensitivity to external QX-314 at low concentrations is typical of the homomultimeric $w v-$ GIRK2 channels expressed in oocytes (Kofuji et al., 1996; Slesinger et al., 1996). The residual current was then blocked by the addition of $0.5 \mathrm{~mm}$ $\mathrm{Cs}^{+}(98 \pm 6 \%$ block; $n=5)$ (Fig. $\left.7 A\right)$. The other major inward rectifier channel sensitive to submillimolar $\mathrm{Cs}^{+}, I_{\mathrm{h}}$, has never been reported to be sensitive to submillimolar external QX-314 (although it can be blocked by $10 \mathrm{~mm}$ internal QX-314) (Perkins and Wong, 1995). An additional four neurons that expressed an inward rectifier current that was insensitive to QX-314 but was readily blocked by $0.5 \mathrm{mM} \mathrm{Cs}^{+}$have not been considered as $w v-I_{\mathrm{IR}}$ and have been discarded from the present analysis. These neurons had a significantly higher membrane capacitance than $w v-I_{\mathrm{IR}}$-expressing neurons $(15.4 \pm 3.2 \mathrm{pF}, n=4$, vs $7.9 \pm 2.5 \mathrm{pF}$, $n=6 ; p<0.01$ ), were autorhythmic, and generated an initial burst followed by a steady discharge during current injection and were probably Purkinje cells.

$w v-I_{\text {IR }}$ was analyzed using tracings obtained after pharmacological block with $\mathrm{Cs}^{+}$for leakage and transient current subtraction after QX-314 sensitivity had been verified $(n=6)$ (compare Fig. $7 A) . w v-I_{\text {IR }}$ had slow kinetics, activating with time constants of tens to hundreds of milliseconds (Fig. 7B), and no fast components could be detected. Voltage dependence was analyzed using Equation 1 (Fig. 8), and average parameter values are reported in Table 2 . The $w v-I_{\mathrm{IR}}$ reversal potential was $\sim 20 \mathrm{mV}$ more positive $(-64.1 \pm 6.3 \mathrm{mV} ; n=4)$ than $C-I_{\mathrm{IR}}$ or $G-I_{\mathrm{IR}}$, consistent with the reduced selectivity of $w v-$ GIRK2 homomultimers for $\mathrm{K}^{+}$ions (Navarro et al., 1996; Kofuji et al., 1996; Slesinger et al., 1996). $w v-\mathrm{I}_{\mathrm{IR}}$ is unlikely to contribute significantly to depolarizing putative granule cells, however, because its activation voltage dependence was steep and confined to negative membrane potentials. Moreover, unlike expression systems, there was no net increase in leakage current in putative weaver granule cells compared with wild-type granule cells (Table 1).

\section{DISCUSSION}

It has been proposed that cerebellar granule cell degeneration in the weaver mutation is induced by either the absence of G-protein modulation or altered biophysical properties of an inward rectifier current (Kofuji et al., 1996; Silverman et al., 1996; Slesinger et al., 1996; Surmeier et al., 1996). In this paper we report that the expression of inward rectifier currents and their G-protein modulation in granule cells of the mice cerebellum are developmentally regulated in situ. In the weaver mutation, the absence of G-protein sensitivity at the premigratory stage appears to be the primary process in the pathogenesis of the mutated phenotype. The possibility that abnormal channel properties are manifest at more advanced developmental stages in surviving granule cells is discussed.

\section{Development of inward rectifier currents in wild-type mice}

We found the earliest functional evidence for inward rectifier current expression in postmitotic premigratory granule cells. In these cells the inward rectifier current was strictly G-proteindependent $\left(G-I_{\mathrm{IR}}\right)$. $G-I_{\mathrm{IR}}$ was also measured in postmigratory granule cells in the first 3 postnatal weeks. In these cells, however, other ionic currents also differed from those in premigratory granule cells (D'Angelo et al., 1994, 1997), allowing action potentials to be generated. In mature granule cells, which generate fast action potentials, a constitutive inward rectifier current was found $\left(C-I_{\mathrm{IR}}\right)$. This may indicate a change in either channel properties or G-protein modulation. On the one hand, the higher voltage sensitivity and the lack of a slow current component in $C-I_{\text {IR }}$ compared with $G-I_{\text {IR }}$ suggest a change in channel properties. GIRK channel properties arise from the assembly of different subunits (Duprat et al., 1995; Kofuji et al., 1995; Krapivinsky et al., 1995), and the expression of slow kinetics depends on the insertion of GIRK1 subunits into GIRK2-containing channels (Slesinger et al., 1996). Therefore a developmental regulation of 
A

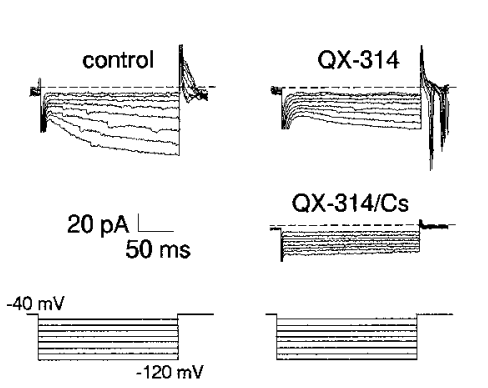

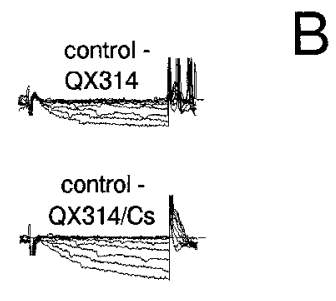

B
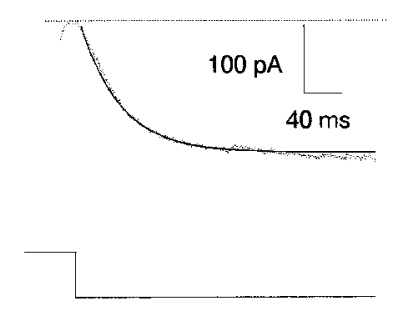

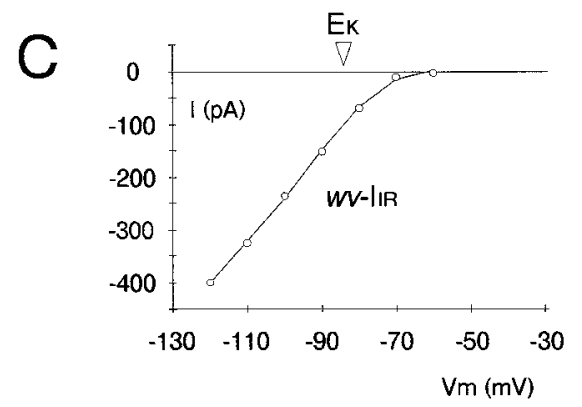

Figure 7. Biophysical and pharmacological properties of the weaver inward rectifier current. $A, w v-I_{\mathrm{IR}}$ was inhibited by $100 \mu \mathrm{M} \mathrm{QX}-314$ and completely blocked by subsequent addition of $0.5 \mathrm{mM} \mathrm{Cs}^{+}$. The QX-314- and QX-314 Cs ${ }^{+}$-sensitive currents have been obtained by subtraction (control - QX-314, control $\left.-\mathrm{QX}-314 / \mathrm{Cs}^{+}\right)$. The voltage-clamp protocol is illustrated at the bottom. B, QX-314 $\mathrm{Cs}^{+}$-sensitive $w v-I_{\mathrm{IR}}$ has been used for kinetic analysis. $w v-I_{\mathrm{IR}}$ was fitted to a single exponential function of the form $i(t)=A 1 \times \exp \left(-t / \tau_{1}\right)+C$. The monoexponential function is superimposed on the experimental tracing $\left(A 1=184 \mathrm{pA} ; \tau_{1}=41.84 \mathrm{msec} ; C=-203.6 \mathrm{pA}\right)$. The tracing was generated by a voltage pulse from $-40 \mathrm{mV}$ to $-120 \mathrm{mV}$. $C$, Because of its slow kinetics, the voltage dependence of $w v-I_{\mathrm{IR}}$ was obtained using steady-state measurements from the QX-314-Cs ${ }^{+}$-sensitive current (see $A$ ). Experimental points have been fitted to Equation 1 to yield the following parameters: $G_{\max }=6.88 \mathrm{nS} ; V_{\mathrm{rev}}=-61 \mathrm{mV} ; V_{1 / 2}=-79.3 \mathrm{mV} ; k=$ $9.5 \mathrm{mV}^{-1}$.

channel subunit expression may contribute to transforming $G-I_{\text {IR }}$ into $C-I_{\mathrm{IR}}$. On the other hand, it seems unlikely that constitutive $C-I_{\text {IR }}$ activation results from a $\mathrm{G}_{\beta \gamma}$-independent channel regulation by intracellular $\mathrm{Na}^{+}$(Silverman et al., 1996), because the pipette solution contained a low intracellular $\mathrm{Na}^{+}$concentration (4 mM) in granule cells expressing both $G-I_{\mathrm{IR}}$ and $C-I_{\mathrm{IR}}$. However, we cannot rule out that changes in G-protein-coupled receptor activation regulate inward rectifier channels (Wickman and Clapham, 1995). Among several neurotransmitters and modulators, glutamate has been shown to regulate granule cell GIRK channels by activating metabotropic receptors (Surmeier et al., 1996).

$G-I_{\text {IR }}$ and $C-I_{\text {IR }}$ were probably both involved in setting the granule cell membrane potential, although in quite different ways. $G-I_{\text {IR }}$ activation extended into the high-voltage range, being well suited to hyperpolarizing the membrane of immature granule cells from its quiescent state at around $-30 \mathrm{mV}$ in response to exogenous modulatory actions. Conversely, $C-I_{\text {IR }}$ was constitutively active in a narrow negative voltage range, tending to clamp the membrane within a negative potential region. In addition to changes in the inward rectifiers, other factors may contribute to stabilizing the resting membrane potential at more negative values in mature rather than immature granule cells, including a lowering in the GABA reversal potential (Brickley et al., 1996) and increased activation of $\mathrm{K}^{+}$currents under muscarinic receptor control (Watkins and Mathie, 1996).

\section{Inward rectifier currents in weaver mice}

Unlike the wild-type cells, premigratory weaver granule cells did not show any inward rectifier currents induced by G-protein stimulation. This probably indicates a loss of G-protein modulation rather than a lack of inward rectifier channel expression, as suggested by the observation that GIRK1, which is expressed in the immature cerebellum, inhibits $w v$-GIRK2-containing channels (Navarro et al., 1996; Slesinger et al., 1996). A loss of G-protein-dependent inward rectifier currents has also been reported in weaver granule cell cultures by Surmeier et al. (1996). It should be noted that no increase in the leakage current was detectable in our experiments (Table 1), as in those of Surmeier et al. (1996) but unlike those of Kofuji et al. (1996).

By recording from putative granule cells that escaped degeneration at the premigratory stage (Sotelo and Changeux, 1974), we found an inward rectifier current with slow kinetics dubbed $w v-I_{\text {IR }}$ that showed constitutive activation and a marked reduction after the extracellular application of low concentrations of QX-314. As well as being sensitive to QX-314, $w v-I_{\text {IR }}$ showed a positive shift in its ionic reversal potential as compared with wild-type currents, consistent with reduced selectivity for $\mathrm{K}^{+}$in favor of $\mathrm{Na}^{+}$and $\mathrm{Ca}^{2+}$ ions. These properties are compatible with the formation of $w v-$ GIRK2 homomultimers (Navarro et al., 1996; Kofuji et al., 1996; Slesinger et al., 1996). However, the identification of $w v-I_{\text {IR }}$ as the native counterpart of $w v-$ GIRK2containing channels is not definitive. First, unlike $w v-$ GIRK2 homomultimers, the neurons expressing $w v-I_{\text {IR }}$ did not show any net increase in leakage current (Table 1). Second, $w v-I_{\mathrm{IR}}$ shares with $I_{\mathrm{h}}$ submillimolar $\mathrm{Cs}^{+}$sensitivity and slow kinetics associated with sagging voltage responses to step current injection. Although the $w v-I_{\mathrm{IR}}$ reversal potential was not as high as expected from $I_{\mathrm{h}}$, the distinction based on QX-314 sensitivity cannot be considered 


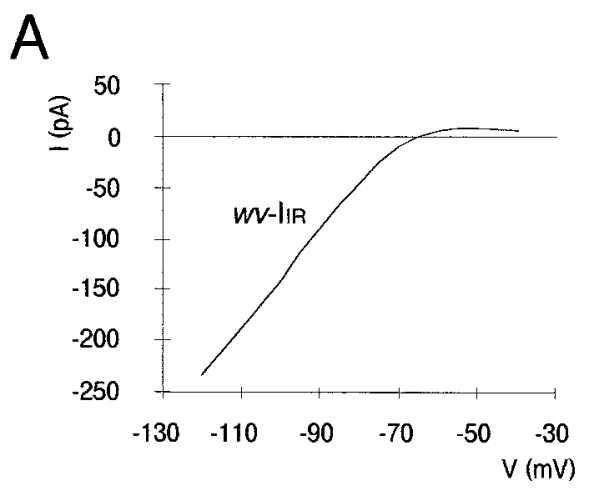

\section{B}
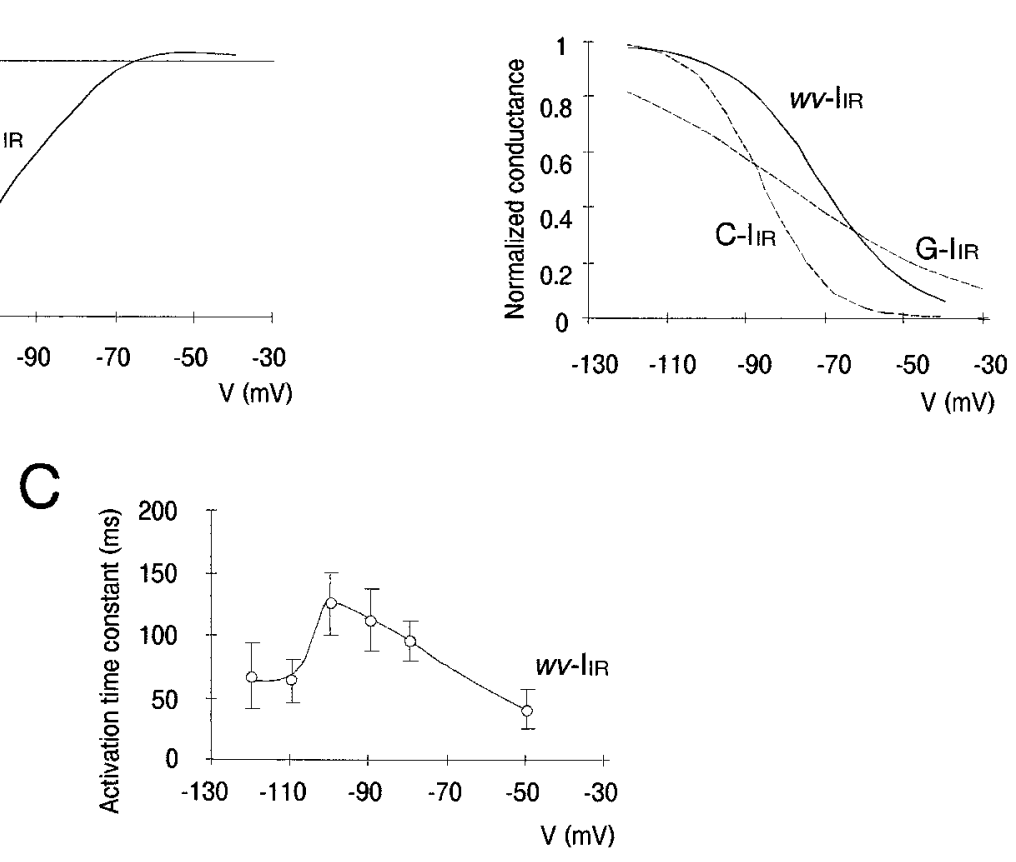

Figure 8. Average kinetics of the weaver inward rectifier currents. $A$, Average $I-V$ plots of $w v-I_{\mathrm{IR}}$ have been reconstructed using Equation 1 and the average values reported in Table 2. $B$, A normalized activation curve of $w v-I_{\mathrm{IR}}$ was reconstructed using Equation 2 . The activation curves of $C-I_{\mathrm{IR}}$ and $G-I_{\mathrm{IR}}$ are replotted for comparison (dotted lines). $C$, Voltage dependence of the fast activation time constant of $w v-I_{\mathrm{IR}}$. Note that the activation time constants are one to two orders of magnitude larger than those of $C-I_{\mathrm{IR}}$ and $G-I_{\mathrm{IR}}$ (compare Fig. $4 C$ ). $A-C$ show that $w v-I_{\mathrm{IR}}$ activation kinetics differs from those of $C-I_{\mathrm{IR}}$ and $G-I_{\mathrm{IR}}$.

as absolute, because a high intracellular QX-314 concentration blocked neuronal $I_{\mathrm{h}}$ (Perkins and Wong, 1995). Finally, although neurons expressing $w v-I_{\text {IR }}$ did not show intrinsic firing discharge or complex spikes, as occurs in $I_{\mathrm{h}}$-expressing Purkinje neurons (Crepel and Penit-Soria, 1986), it is possible that neurons like stellate or basket cells, which have unknown inward rectifier currents, could also have been recorded. Therefore, a direct identification of cell types associated with an extended analysis of inward rectifier currents in cerebellar neurons is needed to confirm the suggestion that $w v-I_{\mathrm{IR}}$ is the native counterpart of mutated $w v$-GIRK2-containing channels.

\section{Pathogenetic implications}

The most important finding in seeking to identify the pathogenetic role of the GIRK mutation (Patil et al., 1995) is that no inward rectifier currents could be induced by G-protein stimulation in weaver premigratory granule cells. These cells cannot use their inward rectifier current $\left(G-I_{\text {IR }}\right)$, which is presumably under the control of specific neuromodulators (Surmeier et al., 1996), to hyperpolarize the membrane from rest. A failure to regulate membrane potential may cause uncontrolled activation of voltage-sensitive $\mathrm{N}$-type $\mathrm{Ca}^{2+}$ channels and NMDA receptors, which in normal conditions drive granule cell motility and differentiation (Komuro and Rakic, 1993a,b), leading to $\mathrm{Ca}^{2+}$ accumulation, neurotoxicity, and death (Garthwaite, 1994; Choi, 1995). The role of NMDA receptors is particularly interesting, because they are stimulated by ambient glutamate in the EGL (Slater and Rossi, 1996) and membrane depolarization unblocks the channel, causing $\mathrm{Ca}^{2+}$ permeation. The absence of $G-I_{\mathrm{IR}}$ activation seems likely to be the major pathogenetic mechanism, because most granule cells degenerate when they are postmitotic in the premigratory region of the EGL (Smeyne and Goldowitz, 1989; Surmeier et al., 1996).

The few granule cells that pass the premigratory stage (Rakic and Sidman, 1973b; Sotelo and Changeux, 1974) might suffer further neurodegenerative damage. To the extent that $w v-I_{\mathrm{IR}}$ is the native counterpart of the mutated GIRK-2 channel expressed in oocytes, it might promote further neurodegeneration through an anomalous $\mathrm{Na}^{+}$and $\mathrm{Ca}^{2+}$ influx (Navarro et al., 1996; Silverman et al., 1996). We noted, however, that the reversal potential remained rather negative and the voltage dependence remained steep, so that $w v-I_{\text {IR }}$ activation was confined to low potentials. Consistently, $w v-I_{\text {IR }}$ was not associated with any marked resting depolarization. We would also point out that constitutive $w v-I_{\mathrm{IR}}$ activation was not specifically related to the pathogenetic process, because a similar property was typical of IGL wild-type granule cells (also see D’Angelo et al., 1995, 1997).

\section{Conclusions}

The inward rectifier in cerebellar granule cells is developmentally regulated, changing from G-protein-dependent to constitutive activation as the granule cells develop from premigratory to postmigratory stages. The G-protein-dependent form probably serves to hyperpolarize the granule cell membrane under the control of specific neurotransmitters and hormones (Kof uji et al., 1996; Surmeier et al., 1996). The failure of inward rectifier G-protein activation identifies an important correlate of the weaver mutation, localizing its functional expression at the premigratory stage. This is probably just the first step in a more complex neurodegenerative process (Hess, 1996), because granule cell development involves cell-cell interactions and the weaver mutation acts nonautonomously (Gao et al., 1992; Gao 
and Hatten, 1993; Hatten and Heintz, 1995). An altered constitutive inward rectifier current may be expressed in weaver granule cells that develop mature excitable properties (Kofuji et al., 1996; Silverman et al., 1996; Slesinger et al., 1996), causing further cellular damage in a two-stage pathogenetic process. Our results support the concept that developmental regulation of GIRK channel subunit expression, and modulation of inward rectifier channel activation, may provide important signals for neuronal survival and differentiation.

\section{REFERENCES}

Brickley SG, Cull-Candy SG, Farrant M (1996) Development of a tonic form of synaptic inhibition in rat cerebellar granule cells resulting from persistent activation of $\mathrm{GABA}_{\mathrm{A}}$ receptors. J Physiol (Lond) 497:753-759.

Choi DW (1995) Calcium: still center-stage in hypoxic-ischemic neuronal death. Trends Neurosci 18:58-60.

Crepel F, Penit-Soria J (1986) Inward rectification and low threshold calcium conductance in rat cerebellar Purkinje cells. An in vitro study. J Physiol (Lond) 372:1-23.

D’Angelo E, Rossi P, De Filippi G, Magistretti J, Taglietti V (1994) The relationship between synaptogenesis and expression of voltagedependent currents in cerebellar granule cells in situ. J Physiol (Paris) 88:197-207.

D’Angelo E, De Filippi G, Rossi P, Taglietti V (1995) Synaptic excitation of individual rat cerebellar granule cells in situ: evidence for the role of NMDA receptors. J Physiol (Lond) 484:397-413.

D'Angelo E, De Filippi G, Rossi P, Taglietti V (1997) Synaptic activation of $\mathrm{Ca}^{2+}$ action potentials in immature rat cerebellar granule cells in situ. J Neurophysiol 78:1631-1642.

Doupnik CA, Lim NF, Kofuji P, Davidson N, Lester HA (1995) Intrinsic gating properties of a cloned $\mathrm{G}$ protein-activated inward rectifier $\mathrm{K}^{+}$ channel. J Gen Physiol 106:1-23.

Duprat F, Lesage F, Guillemare E, Fink M, Hugnot JP, Bigay J, Lazdunsky M, Romey G, Barhanin J (1995) Heterologous multimeric assembly is essential for $\mathrm{K}^{+}$channel activity of neuronal and cardiac G-protein-activated inward rectifiers. Biochem Biophys Res Commun 212:657-663.

Edwards FA, Konnerth A, Sakmann B, Takahashi T (1989) A thin slice preparation for patch-clamp recordings from neurons of the mammalian central nervous system. Pflügers Arch 414:600-612.

Gao WQ, Hatten ME (1993) Neuronal differentiation rescued by implantation of weaver granule cell precursors into wild-type cerebellar cortex. Science 260:367-369.

Gao WQ, Liu X-L, Hatten ME (1992) The weaver gene encodes a nonautonomous signal for CNS neuronal differentiation. Cell $68: 841-854$.

Garthwaite J (1994) NMDA receptors, neuronal development, and neurodegeneration. In: The NMDA receptor (Collingridge GL, Watkins JC, eds), pp 428-456. Oxford: Oxford UP.

Hatten ME, Heintz N (1995) Mechanisms of neural patterning and specification in the developing cerebellum. Annu Rev Neurosci 18:385-408.

Hess EJ (1996) Identification of the weaver mouse mutation: the end of the beginning. Neuron 16:1073-1076.

Hille B, Schwarz W (1978) Potassium channels as multi-ion single-file pores. J Gen Physiol 72:409-442.

Kofuji P, Davidson N, Lester HA (1995) Evidence that neuronal G-protein-gated inwardly rectifying $\mathrm{K}^{+}$channels are activated by $\mathrm{G} \beta \gamma$ subunits and function as heteromultimers. Proc Natl Acad Sci USA 92:6542-6546.

Kofuji P, Hofer M, Millen KJ, Millonig JH, Davidson N, Lester HA, Hatten ME (1996) Functional analysis of the weaver mutant GIRK2 $\mathrm{K}^{+}$channel and rescue of weaver granule cells. Neuron 16:941-952.

Komuro H, Rakic P (1993a) Selective role of N-type calcium channels in neuronal migration. Science 257:806-809.

Komuro H, Rakic P (1993b) Modulation of neuronal migration by NMDA receptors. Science 260:95-97.

Krapivinsky G, Gordon EA, Wickman K, Velimirovic B, Krapivinsky L, Clapham DE (1995) The G-protein-gated atrial $\mathrm{K}^{+}$channel $\mathrm{I}_{\mathrm{KACh}}$ is a heteromultimer of two inwardly rectifying $\mathrm{K}^{+}$channel proteins. Nature 374:135-141.

Marchetti C, Amico C, Usai C (1995) Functional characterization of the effect of nimodipine on the calcium current in rat cerebellar granule cells. J Neurophysiol 73:1169-1180.

Navarro B, Kennedy ME, Velimirovic B, Bhat D, Peterson A, Clapham DE (1996) Nonselective and $\mathrm{G} \beta \alpha$-insensitive weaver $\mathrm{K}^{+}$channels. Science 272:1950-1953.

Patil N, Cox DR, Bhat D, Faham M, Myers RM, Peterson AS (1995) A potassium channel mutation in weaver mice implicates membrane excitability in granule cell differentiation. Nat Genet 11:126-129.

Perkins KL, Wong RKS (1995) Intracellular QX-314 blocks the hyperpolarization-activated inward current Iq in hippocampal CA1 pyramidal cells. J Neurophysiol 73:911-915.

Pitzer KS, Mayorga G (1973) Thermodynamics of electrolytes. II. Activity and osmotic coefficients for strong electrolytes with one or both ions univalent. J Physical Chem 77:2300-2308.

Rakic P, Sidman RL (1973a) Sequence of developmental abnormalities leading to granule cell deficit in cerebellar cortex of weaver mutant mice. J Comp Neurol 152:103-132.

Rakic P, Sidman RL (1973b) Organization of cerebellar cortex secondary to deficit of granule cells in weaver mutant mice. J Comp Neurol 152:133-162.

Silverman SK, Kofuji P, Dougherty DA, Davidson N, Lester HA (1996) A regenerative link in the ionic fluxes through the weaver potassium channel underlies the pathophysiology of the mutation. Proc Natl Acad Sci USA 93:15429-15434.

Slater NT, Rossi DJ (1996) Functional expression of NMDA receptors in developing neurons. In: Excitatory amino acids and the cerebral cortex (Conti F, Hicks TP, eds), pp 215-226. Cambridge, MA; MIT.

Slesinger PA, Patil N, Liao YJ, Jan YN, Jan LY, Cox DR (1996) Functional effects of the mouse weaver mutation on $G$ protein-gated inwardly rectifying $\mathrm{K}^{+}$channels. Neuron 16:321-331.

Smeyne RJ, Goldowitz D (1989) Development and death of external granular layer cells in the weaver mouse cerebellum: a quantitative study. J Neurosci 9:1608-1620.

Sotelo C, Changeux JP (1974) Bergmann fibers and granular cell migration in the cerebellum of homozygous weaver mutant mouse. Brain Res 77:484-491.

Spitzer NC (1991) A developmental handshake: neuronal control of ionic currents and their control of neuronal differentiation. J Neurobiol 22:659-673.

Surmeier DJ, Mermelstein PG, Goldowitz D (1996) The weaver mutation of GIRK2 results in a loss of inwardly rectifying $\mathrm{K}^{+}$current in cerebellar granule cells. Proc Natl Acad Sci USA 93:11191-11195.

Watkins CS, Mathie A (1996) A non-inactivating $\mathrm{K}^{+}$current sensitive to muscarinic receptor activation in rat cultured cerebellar granule neurons. J Physiol (Lond) 491:401-412.

Wickman KD, Clapham DE (1995) G-protein regulation of ion channels. Curr Opin Neurobiol 5:278-285. 